University of Nebraska - Lincoln

DigitalCommons@University of Nebraska - Lincoln

Faculty Publications: Department of Teaching, Department of Teaching, Learning and Teacher Learning and Teacher Education

Education

2021

Picturing dual language and gentrification: An analysis of visual media and their connection to language policy

Edmund T. Hamann

Theresa Catalano

Follow this and additional works at: https://digitalcommons.unl.edu/teachlearnfacpub

Part of the Curriculum and Instruction Commons, and the Teacher Education and Professional

Development Commons

This Article is brought to you for free and open access by the Department of Teaching, Learning and Teacher Education at DigitalCommons@University of Nebraska - Lincoln. It has been accepted for inclusion in Faculty Publications: Department of Teaching, Learning and Teacher Education by an authorized administrator of DigitalCommons@University of Nebraska - Lincoln. 


\title{
Picturing dual language and gentrification: An analysis of visual media and their connection to language policy
}

\author{
Edmund T. Hamann \& Theresa Catalano \\ Department of Teaching, Learning, and Teacher Education, \\ University of Nebraska-Lincoln, Lincoln, NE 68588-0355, USA \\ Correspondence - Edmund T. Hamann, ehamann2@unl.edu \\ ORCID \\ Edmund T. Hamann http://orcid.org/oooo-0003-0566-4431 \\ Theresa Catalano https://orcid.org/00oo-0002-7519-030X
}

\begin{abstract}
Dual language (DL) programs propose to be vehicles of social justice and transformation by valuing an additional language other than the dominant one in a society and thereby contesting language hierarchies and the subordination of those who speak/use a non-dominant language (Flores, Flores, Educational Policy 30:13-38, 2016; Menken and García, Menken, K., \& García, O. (2021). Constructing translanguaging school policies and practices. In: CUNY-New York State Initiative on Emergent Bilinguals (Eds.) Translanguaging and transformative teaching for emergent bilingual students. Project. Routledge, New York.). However, Palmer (Henderson, K. I., \& Palmer, D. K. (2020). Dual Language Bilingual Education: Teacher Cases and Perspectives on Large-scale Implementation. Multilingual Matters.: 11) warned that DL programs risk becoming "enrichment foreign-language immersion to middle- and upper-class White children" and hence "lost opportunit[ies]
\end{abstract}

Published in Language Policy, 2021.

doi:10.1007/s10993-021-09585-1

Copyright (C) 2021 Edmund T. Hamann \& Theresa Catalano. Published under exclusive license to Springer Nature B.V. Used by permission.

Submitted 25 February 2020; accepted 10 April 2021; published 3 May 2021 
for transformation." This "gentrification" of DL efforts is enabled by racial, economic, and linguistic hierarchies of power (Valdez, Freire, and Delavan, Valdez et al., The Urban Review 48:601-627, 2016). Our analysis of five images from a corpus of 34 online news articles considers how photographic depictions of DL programs can manifest gentrification in non-linguistic ways that nonetheless reinforce moves away from DL for social transformation and toward DL as hegemonic. This paper clarifies how multimodal critical discourse analysis (MCDA) and Habermasian notions of the public sphere critically complement how public spaces (in this case schools) get imbued with "specific values that mediate inhabitants' interpretations of themselves and their relation to others in a space" (Hult, Hult, Tollefson and Pérez-Milans (eds.), The Oxford handbook of language policy and planning, Oxford University Press, 2018: 338). Findings reveal nuanced ways in which world language populations are protagonized visually and related ways that heritage/maintenance populations are either erased or marginalized. This helps explain the key assertion-that visual images can reinforce DL program gentrification-but also augments the theoretical toolkit available to study how progressive intentions of DL can become co-opted.

Keywords: Dual language, Gentrification, Multimodal critical discourse analysis, Public sphere

\section{Introduction}

Dual language programs (also called dual language immersion, or oneway/two-way immersion) are becoming increasingly popular, but research indicates that this popularity is growing in particular amongst White, non-Hispanic, middle-class, English-speaking parents (e.g., Valdez et al. 2016), prospectively leading such programs away from the social justice orientations that may have informed their founding logics (Flores, 2016). Dual language (DL) is an umbrella term that refers to "any program that provides literacy and content instruction to all students through two languages, and that promotes bilingualism and biliteracy, grade-level achievement, and multicultural competence for all students" (Howard, Lindholm-Leary, Sugarman, Christian, \& Rogers, 2007: 1). This includes both one-way (when serving minoritized language speakers or foreign language immersion when serving initially English-dominant speakers) and two-way programs in which "English dominant children are intentionally integrated with speakers of another language (usually Spanish) in bilingual classrooms with the goal of bilingualism and biliteracy for all children" (Palmer \& Martínez, 2013: 283). 
Palmer (2010: 11) cautioned that without attention to dynamics of race and power, DL programs could become "enrichment foreignlanguage immersion to middle- and upper-class White children" and hence be "lost opportunit[ies] for transformation." As such, her work is part of a broader tradition tying together language education with circulating discourses around language, immigration, globalization, and nation-state formation in terms of both ethics and power (Combs et al. 2011). Recent scholarship (beginning with Valdés's [1997] “cautionary note" that DL programs could become another way to disenfranchise Latinx students by prioritizing the learning of White students) has focused on a gentrification trend in which DL programs focus more on privileged/world language constituencies than on minoritized heritage language ones.

Although much work has examined various aspects of gentrification in DL programs (cf. next section), few studies examine the way these discourses play out visually- i.e., through image or other modeswhich means that we are only seeing part of the picture (pardon the pun). To fill this gap, this article is part of a larger study in which we examined 35 images (mostly photojournalism with a few stock photos) from a corpus of 34 newspaper articles about local DL programs to gain an understanding of the ways DL programs are represented visually to the public (cf. Catalano, 2020). As per the topic of this Special Issue, we chose to focus on five images from this corpus which in different ways visually reinforce gentrification.

Considering how the semiotics of representations (e.g., photographs) inform/ shape language policy and planning (LPP), we employed multimodal critical discourse analysis (MCDA) to deconstruct the semiotic resources and meaning potentials in the images and relate them to wider discourses and ideologies pertaining to DL programs. The research question that guided our study was: To what extent is gentrification operating in these visual images that accompany depictions of DL programs and how does it operate to privilege or marginalize those who endeavor in such spaces, like students of various backgrounds? Additionally, we incorporate theoretical frameworks from Habermasian notions of the public sphere (Calhoun, 1992) to situate and further explain our focus on equity in media representation and theorize the interface between civil society (e.g., parents, newspaper readers) and the state (as embodied here by public schools). 
These frameworks aid us in considering how visual imagery contributes to public sphere discourses and the 'theories in use' (Argyris \& Schön, 1975) that interface with policy implementation.

However, before we get to the semiotics of representation and their very real consequences for learners and the programs they are part of, we must first situate what we know so far about gentrification and DL programs. We then need to locate our consideration of DL gentrification within a broader review of LPP that uses Johnson and Johnson (2015) to make explicit the unequal distribution of power that is more tacit in Spolsky's (2004) foundational tripartite framing of the field.

\section{Gentrification and dual language programs}

Gentrification is a metaphor that compares inequity in multilingual language programs to the way urban neighborhoods are renovated to conform to middle-class tastes, often forcing current inhabitants to move from their homes to seek lower-cost housing elsewhere. In terms of DL programs, gentrification references the extent to which these programs cater more to the needs of affluent privileged students (the attracted population) than to the students, usually students of color, who bring familiarity with the second, non-dominant language of the program. Valdez et al. (2016) “coined the term 'gentrification' to describe trends in DL that have pushed out [English learners] and other non-privileged students from multilingual education options" (p. 6o4). Their study of policy documents found that already privileged groups were being targeted for participation in the programs and resulted in a decrease in access to the programs for heritage/maintenance populations (i.e., those wanting to study the language to maintain family connections and identity).

In a US context, in a Spanish-English DL program, this less-valued second population would be those who arrive with developed familiarity with Spanish from family, community, and/or migration. In essence, concern about gentrification in DL programs is a concern that students coming from one background (English as a home language, with acquisition of a second language as a 'bonus' assisted by peers with familiarity with that language) are prioritized over students whose language background has not been primarily in English 
and whose academic development of a home language would contest the subtractive hazard of non-English repertoires not counting. One of the manifestations of gentrification in multimodal representations of DL would be prioritizing White middle-class bodies (who get agentive roles) in relation to those of anonymous brown bodies (who get support roles).

Burns (2017) came at the gentrification issue from the angle of parent involvement. She explored how whiteness operates in DL classrooms under the theoretical frame of interest convergence (e.g., it benefits White students to have native Spanish-speakers in class with them). She found that although school administrators attempted to work against the domination of White parents in the programs, structural factors nonetheless led to them having more power and influence. Ironically, just as those who move into gentrifying neighborhoods can be attracted to its disappearing 'authenticity', many of the politically more powerful White parents interested in their children's enrollment in DL programs may see that enrollment as part of their own liberal stance of resistance to contemporary xenophobic discourses. The "gentrifiers" may not see or care to acknowledge their own contributions to the hazards of gentrification.

Heiman and Yanes (2018) reiterated and empirically chronicled Valdés's (1997) caution about two-way programs often becoming means to disenfranchise Latinx students by prioritizing the learning of White students. In their ethnography of a rapidly gentrifying two-way DL school, they documented one teacher's language-as- empowerment framework as a way to resist this trend. Heiman and Murakami (2019) concentrated on how gentrification processes impacted the principal and vice principal and resulted in Spanish-speaking families being pushed out of DL programs. In their inquiry, they highlight the need for administrators to develop a critical consciousness about the original social justice aims of DL programs-i.e., valuing minoritized students' linguistic and other background knowledge as resources to more fully develop.

Besides studies that have examined gentrification, other studies have looked at the discourse used to talk about DL programs and how these incorporate wider societal discourses that index gentrification. For example, in Henderson's (2019) multimethod, multi-site, comparative analysis examining educator discourses addressing student 
participation in DL programs in Utah and Texas, she found that competing discourses worked to exclude students struggling academically or linguistically from the programs despite such students' access to these programs being a social justice issue. She concludes by encouraging DL program implementers to represent students labeled as 'English learners' as participants in DL programs. Henderson and Palmer (2020) explore teachers' roles in DL in light of top-down initiatives at the state and district levels. Through case studies, they show how teachers (viewed as makers of their own language policy) implement the programs and interpret the policies, highlighting discourses of English learner exclusion (or, in other cases, majoritarian inclusion).

Valdez et al. (2016) have produced a substantial body of scholarship in this area (as have other authors in this Special Issue) and are the only other DL gentrification scholars we found who also engage in visual analysis. In their 2016 study, they focused on gentrification trends and the way in which DL discourse signals these trends. In a different study (Freire et al. 2017), the same authors examined Utah DL state policy documents, websites, and promotional materials and found that the discourse behind the rise in DL for the world language constituency was driven largely by neoliberal forces, which they defined as "a pattern of seeing all social phenomena through the lens of economic markets, but without an emphasis on the inequalities that accompany all markets" (p. 278). They also found that the discourse was "consistent with the patterns of racializing Latinas/os as threatening to the dominance of Whites and Spanish as threatening to the cultural status quo in the U.S." (2017: 286). Multilingualism was valued when it could also benefit dominant groups (e.g., interest convergence, cf. Burns, 2017).

Furthermore, "Spanish speakers were the most visually exoticized language group across the materials" (Freire et al. 2017, p. 284). As Burbules (1996: 115) asserted, when people are exoticized in images they can be seen as "quaint, charming, or curious in a strange, fascinating way-but still viewed and evaluated from a dominant point of view." Hence, although it is still celebratory, "it nevertheless places the exoticized other hierarchically lower" (Freire et al. 2017: 284). For example, on the Spanish DL brochures and home page, heritage/maintenance speakers were shown in costumes performing cultural traditions, whereas on the English DL homepage there was a photo "of 
a racially diverse group of children in a parade carrying and dressed in American flags" (p. 284). Hence, despite multilingual discourses found in the documents, the images communicated English hegemony and the discourse that "English remains the most American of the languages" (p. 284).

Delavan et al. (2017: 88) divided the constituents of DL programs into three groups-maintenance, heritage, and world language-and, similar to their other studies, they noted a heavy emphasis on Global Human Capital discourses (i.e., neoliberalism) which made invisible issues of inequality as well as the interests of local, non-White, heritage and maintenance constituencies. In the brochures, videos, and websites they examined, the world language constituencies were the main visual protagonists of the narrative while "non-White, maintenance, and heritage constituencies were depicted in small numbers as protagonists but were mostly seen as non-protagonists and "minor characters in the narrative" (often exoticized) (p. 95). They did acknowledge there was some effort to depict more than just Utah's White majority in the promotional materials, but it wasn't systematic. Hence, the audiences of the materials mainly viewed "racial appearances most associated with the world language constituency in the United States" (p. 95).

\section{Theoretical framework}

\section{Language education policy and planning}

To understand DL program gentrification as LPP requires a framing of policy that does not see it as only or mainly 'top-down'. Fortunately, since at least the late 196os when Lipsky (1969) introduced the term "street-level bureaucrat," such a traditional top-down perspective has become increasingly anachronistic and scholars as varied as (alphabetically) Meredith Honig, Bradley Levinson, Milbrey McLaughlin, Jim Spillane, Cris Shore, Peggy Sutton, and Sue Wright have theorized policy as a co-creation across tiers of formal and informal governance. They (and others) have increasingly made allowance for those not identified in traditional policy creation and implementation sequences at all (like parents) as nonetheless relevant policy actors. 
While these researchers do not necessarily forefront language policy as their specific domain of interest, language policy scholars such as Johnson and Johnson (2015) draw directly and indirectly from their legacy, emphasizing power, agency, and co-optation in ways that are more overt than is sometimes the case in some foundational (read older) language policy scholarship. Johnson and Johnson explain:

Johnson (2013a) portrays LP layers as processes of creation, interpretation, and appropriation. In this conceptualization policies are first created as a result of intertextual and interdiscursive links to past and present policy texts and discourses. Once a policy has been created and put into motion, it is open to diverse interpretations, both by those who created it, and by those who are expected to appropriate it in practice. (p. 223)

Their study examined how nominally identical school district-level language programs in Washington state, which were funded under the same state-level language policy, nonetheless ended up being different in practice because of pressure from English-speaking parents. To frame a study like ours, Johnson and Johnson help us see actors (like parents) and those who shape the public sphere (like photojournalists) as contributors to LPP as enacted and as consequential. Yet they also remind us that these non-traditional policy actors' agency is often heavily shaped by context: "Social agents with access to institutional power tend to make policy decisions in line with dominant discourses that sustain and normalize linguistic, economic, and ethnic/ social hierarchies" (p. 223). Elegantly, this theoretical framing leaves intact both original and macro intentions of LPP (which in our case would be the inclusive, heritage language and culture-honoring prospect of DL programs) and the ways local actors can distort or subvert these intents in local implementation, replacing transformative praxis instead with the hegemonic. Crucially, given the different outcomes in Johnson and Johnson's two examples, that co-optation is possible does not make it inevitable.

Yet before we endeavor to link Habermasian notions of the public sphere to how these processes might proceed, we need to turn to some older LPP research to clarify one more point-why visual images, in our case photographs accompanying accounts of DL programs, 
might be understood as LPP artifacts-i.e., data points that an LPP study can consider. Spolsky (2004), author of widely cited and eponymously titled book Language Policy, suggested a tripartite characterization of language policy that distinguishes the habitual (reflecting norms) from situated values (discrete beliefs about particular languages) and language management (deliberate attempts to manipulate language practices or beliefs). These distinctions matter as we extend LPP analysis into nonlinguistic domains by examining photographs, as photographs can both reflect and shape norms. The photojournalists and editors who took the photographs we examine and selected them to accompany articles were not primary drivers of language management and their invocation of beliefs about language in selecting the photos was probably tacit, which leaves us with the habitual. Although we will need to develop several ideas further before returning to this point, we assert that the selected photographs embed norms about who education programs should be for or, more accurately, who is prioritized. By providing readers with first impressions of a story about DL (expecting prospective readers to see the photos and headline before opting to read or not read an article and having the photo shape expectations regarding what the article says), these photographs embed ideas that shape LPP, that, in these cases, naturalize DL gentrification.

To illuminate how these photos support DL gentrification and to extend LPP analysis to include analysis of nonlinguistic features that reinforce linguistic themes requires turning to two complementary domains of social inquiry-multimodal critical discourse analysis (MCDA) and Habermasian notions of the public sphere. MCDA helps us conceptualize the relationship between language and other topics of semiotic (communicative-sign-based) inquiry, while dualistic notions of the public sphere (both the idea as originally advanced and also how its premise of democratic inclusion was substantively critiqued) help us socio-locate the individual actors, in this case the photojournalists and editors, who have linked these images to public domain news about DL programs. As has long been noted, the mass media "play a crucial role in the persuasive reproduction of dominant ideologies in general, and of ethnic ideologies in particular...The media not only express, reflect, or disseminate ethnic opinions, but actively mediate them, both among the various power elites themselves, as well as between the elites and the public" (van Dijk, 1988: 213). 


\section{The Habermasian public sphere}

Educational research has shown that media discourse plays an important role in the formation of education policy (Gerstl-Pepin, 2007). Many people rely on media outlets to inform their thinking about schooling more broadly (Howell, 2008; West et al. 2011) and, as such, news coverage of educational issues shapes which issues are seen as important. By looking at what is included, excluded, or made salient in local online news sources, we can see which issues are considered important and what discourses are invoked to help us understand the topics (Coe \& Kuttner, 2018). This inclusion, exclusion, valuing, dismissing, ignoring, etc. in the media is by definition public.

Our inquiry is rooted in the idea that the images we examine both reflect and contribute to public understandings of what DL programs are and, centrally relevant to the topic of gentrification, who they should serve. In this vein, we would do well to remember several insights by Blommaert (2013). First, visual representations are not language per se, but they can be examined semiotically. Semiotics helps us to "see signs as material forces subject to and reflective of conditions of production and patterns of distribution, and as constructive of social reality as real social agents having real affects in real life" (Blommaert, 2013: 38). Secondly, "Messages in the public space are never neutral, they always display connections to social structure, power, and hierarchies (Blommaert, 2013: 40). Finally, by focusing on semiotization, "we can turn space into a genuinely ethnographic object full of traces of human activity, interactions, relations, histories and anticipated futures" (Blommaert, 2013: 48). Boiled down, visual representations in mainstream media inform and reflect the public sphere, including the reality that some have more privileged access to shaping that sphere and thereby informing governmentality (Calhoun, 1992) or policy and policy implementation (Hamann \& Reeves, 2012) than others.

German social theorist Jurgen Habermas (1989, orig. 1962) was concerned with the interface between civil society and state in democracies and identified the media as a key two-way intermediary between the two. Media portrayed civil society sensibilities to the state, thus becoming a means for civic or social goals to be incorporated into the instrumentality of the state (which can include 
schooling). In turn, media also represented the state back to civil society, reporting on (and/or visually representing) governmentality back to the populace.

Habermas was emphatic that this public sphere was not the same as the state (Calhoun, 1992). It was a separate and examinable domain for a crucial contestation of ideas and in that contestation the society's determination and redetermination of what could and should be. As such, he saw the public sphere as a key democratic check on the state. However, critics (e.g., Fraser, 1992; Garnham, 1992) have noted that not all voices have equal access to the public sphere, i.e., not all voices are equally powerful or heard. Garnham distinguishes a "plebeian public sphere" as coexisting alongside and sometimes in opposition to a "bourgeois public sphere" (1992: 359).

One of us, in an examination of the way mainstream print media represented school, student, teacher, and community dimensions of six concurrent 2006 ICE raids on Swift Corporation meatpacking plants (and the challenge of whether students had parents to go home to; see Hamann and Reeves [2012]), invoked both Habermas's notion of the public sphere and its critique to consider local print media representations of those raids and, in turn, what that said about local sensemaking about those raids. The relevant insights for this paper are (1) that print media reflected local 'mainstream' attitudes and that, as 'mainstream' attitudes, those were not necessarily stances of the entirety of the community, but (2) that in framing both educators 'and families' responses to the raids the media also were shaping/reiterating understandings of what schools (i.e., local manifestations of the state) do. Local print media depictions came from a similar comparatively privileged social location as do White, professional parents interested in enrolling their children in DL programs and articulated what kind of institutions schools should be.

Applying a public-sphere framing to the earlier visual examples from Freire et al. (2017), the English language website's depiction of a diverse group of children marching around with an American flag both reflected and helped shape a stance that learning English was patriotic. More subtly, images like that hint at what problems a program exists to solve, including who it supposed to serve and how. Emphasizing the public sphere here returns our focus to the interface between civil society and the state and whether democratic 
processes are challenging or enabling the continued heeding of some voices over others and some values over others. The marching children were not the state, but it was a manifestation of the state (the website) that both reflected back and helped interpret what the children's activity meant.

\section{Multimodal critical discourse analysis}

Multimodal Critical Discourse Analysis (MCDA) is a conceptual framework that combines theories from social semiotics and multimodality with that of critical discourse studies (CDS). CDS scholars assert that language is a site for social struggle and for the ways that reality is defined (Richardson 2006). From this perspective, language does not just help us communicate, but it constructs reality (Ledin \& Machin, 2018). CDS provides us with tools of analysis that can be used to find 'discourses' present in texts. 'Discourses' according to Foucault (1977) are "accepted understandings of how things work" that provide the basis for "what we do, how we plan and organize" (Ledin \& Machin, 2018: 28). CDS aims to help us understand the way language figures in issues such as power and ideology, but also how language serves the interests and values of people in power (Flowerdew and Richardson 2018).

The ultimate goal of CDS is to expose the way discourse can perpetuate social patterns, by naming/highlighting those patterns in order to bring about social change. The fields of social semiotics and multimodality are helpful in applying the aims of CDS to visual communication. Social semiotics is concerned with not just language, but any process "of meaning making (i.e., signification and interpretation or what is called semiosis)" and how they "shape individuals and societies” (Jewitt, Bezemer, \& O’Halloran, 2016: 58). Multimodality, which emerged from social semiotics in the 1990s, also emphasizes the many ways that people make meaning in society and the importance of looking at all modes included in a text (e.g., image, sound, gesture, emojis, bullet points) in order to see the complete message (Jewitt et al., 2016). Since this article examines communication through local news sources, MCDA tools for analysis of photojournalism are particularly helpful in analyzing photographs, and we draw on work from Sontag (1973), Barthes (1977), Lutz and Collins (1993), Kress and van Leeuwen (2006), Machin (2007), van Leeuwen (2008), and Ledin and 
Machin (2018) in our analysis of the photos in our data set. Below we describe specific tools we used from these scholars to aid in our analysis of the photographs.

\section{Methodology}

\section{Data collection}

Momentarily we will focus on five representative images of DL program gentrification derived from a larger set of 35 images that accompanied 34 local print media stories about DL programs, but it is important to briefly trace our initial larger project (which has led to other publications in addition to this one [e.g., Catalano, 2020]). We found those 34 stories by searching in Google for the terms "dual language," "dual language immersion," and "two-way immersion.” We further constrained our search by restricting it to the 2018 calendar year (that was the most recent full calendar year before the April 2019 AERA meeting where we shared the earliest version of this article), only including stories that were at least 200 words long (figuring that anything shorter did not constitute a sufficient story/account), and only looking at stories that included both text and photographic images. The 34 stories and 35 images identified this way came from 13 states that were as geographically varied as Texas, New York, Nebraska, and Illinois.

We feel confident that our initial search was nationally representative, but it had the limitation that there are surely visual images related to DL programs shared in other media (e.g., program brochures, local TV news stories, etc.) that would also be consequential for understanding how these programs are portrayed in the public sphere, but not captured by our search strategy. Our goal was not to measure the proportion of public images that support or counter a gentrification dynamic, but rather to create a proof of concept that shows how visual images can reiterate gentrification messages and therefore merit inclusion in analyses that consider what shapes language policy as praxis.

The images selected for discussion here are the five that best allowed us to illustrate how gentrifying ideologies of DL might be both reinforced by and displayed in public sphere visual representations 
(i.e., images) of such programs by either targeting particular audiences or communicating particular things about those enrolled in the programs. For example, there were numerous images in the larger corpus in which many students were shown with their backs to the camera in similar poses with the teacher at the whiteboard in front of the class. We chose only one of those photos to focus on here. Similarly, there were many signs designating language allocation or hierarchy, and we chose only one of those to discuss in order to provide a more varied picture of how gentrification manifested itself in the data. Thus, our chosen sample sufficed for the focus of this paper-to consider the ways that gentrification is communicated visually.

In our larger dataset there were no images that challenge a gentrification interpretation. For example, we did not find images that struck us as counter-hegemonic, such as would a Mexican American student speaking with her family in Mexico (suggesting the value of maintaining one's linguistic heritage) or African American students portrayed holding Spanish language flashcards (to denormalize the use of White students to represent the world language constituency). Rather, the excluded images are things like a photograph of the front of a school that, as images, are largely silent one way or another about the expected values, priorities, or constituencies of a program.

\section{Data Analysis}

After we selected representative samples of images that illustrated in some way gentrification ideologies, we created a smaller, imageonly file and coded these images as to how they reflected or constituted gentrification trends and we incorporated tools and theories from MCDA to aid in our analysis. However, because one of the tenets of multimodality is the importance of looking at not just each mode of communication but also at the combination of them (Bateman \& Wildfeuer, 2014), the accompanying written text for each image was also examined in order to understand how the photographs were anchored in meaning. Nonetheless, we forefronted attention to the affordances of the photographs more than the linguistic elements in the articles in accordance with our goal to highlight how more than textual elements can be examined as mechanisms that frame language policy (in this case, gentrification of DL programs). 
Four considerations of photographic representation orient our analysis. First, we considered three elements always present when analyzing photographs; angle, distance, and gaze ${ }^{1}$ (Kress \& van Leeuwen, 2006). We drew on perspectives from the research arguing that camera angles carry meaning potential and can communicate differences in power. For example, downward angles often signify symbolic power over someone, literally physically looking down on them, which is the photographic equivalent of the hierarchy implied in the metaphorical expression 'to look down on someone'. In the same way, upward angles communicate symbolic power over the viewer, and can convey reverence or respect (e.g., the metaphorical expression 'to look up to someone' hails from the embodied experience of physically looking up at an older sibling or adult). Horizontal angles can express involvement or detachment. When the subject is looking directly at the viewer as if asking something of him/her, this is called a demand gaze. In contrast, offer images are when the subject is not engaging with the camera and as such, the viewer becomes a type of "voyeur," watching, but not being asked to do something. These kinds of images can signify detachment and/or "objectivation" (van Leeuwen, 2008: 141). In the same way, close-ups make us feel closer to subjects, showing us their emotions and expression. In turn, distant shots allow us to feel distant emotionally from the subjects, impersonalize people, and make them seem more like general types, rather than individuals we might know (Ledin \& Machin, 2018).

Second, we considered the difference between denotation (what is documented in the photograph) and connotation (the ideas and valued communicated by the photograph) which also matter greatly in a visual analysis (Barthes, 1977). Conveyors of meaning include poses, facial expressions, objects, clothing, settings, color, layout, font, etc. For representations of social practices, we also considered whether people were seen as individuals (e.g., by looking at the camera) or were more likely to be categorized as part of a particular cultural group (collectivization).

1 Kress and van Leeuwen (2006: 4) warn that visual language is not transparent and universally understood, but rather, culturally specific. As such, the framework presented here is biased toward Western visual communication, and makes no claims toward the application of these ideas to other cultures. Still, within Western visual design (which entails the US context of this study), these theories can be applied to visual communication. 
Third, we examined the way people engaged in actions in order to consider underlying ideas and values communicated in the images. We drew on research that argues, for instance, that when people are shown doing material processes (e.g., throwing something, lifting something), they are seen as having more agency or power in an event. When they are depicted in mental (e.g., thinking) or behavioral processes (e.g., watching, listening), this connotes less agency or power. Emotional processes such as smiling or crying connote feelings or moods about the topic being covered (Ledin \& Machin, 2018). In a critical analysis, it is also important to look at who is not shown in the images. In this case, we looked for which types of DL students (e.g., world language or heritage/maintenance) were depicted.

Fourth, we explored how the representation of events/actions/people compared to the events/actions/people themselves. Photographs "not only represent what is going on, they also evaluate it, ascribe purpose to it, justify it, and so on, and in many texts these aspects of representation become far more important than the representation of the social practice itself" (van Leeuwen, 2008: 6). Hence when analyzing the images, we considered whether what we saw in the images was framed (Goffman \& Rodríguez, 2006) in a particular way in order to convey something that the photojournalist and/or editor wanted to convey about DL programs and the people in them (in order to complement or contrast with the written text) and whether or not this accurately reflected the programs themselves.

We now turn to the five selected images for this study. For each, following Machin and van Leeuwen's (2016) model for MCDA, we first describe it according to the elements introduced in our Data Analysis section along with any important contextual information from the written text in the article. We then interpret the visual elements based on experiential meaning potential (e.g., personal experiences such as lightness and darkness as it relates to day and night) or cultural provenance (e.g., the color green "can be interpreted as indicating 'concern for the environment' on the basis of documentary evidence" or when comparing with other texts in which "this meaning is linguistically anchored" [Machin \& van Leeuwen, 2016: 252]). Additionally, we propose the wider significance of the images relating them back to our topic of gentrification and our combined theoretical frames. Finally, we acknowledge that our appraisals of visual images 


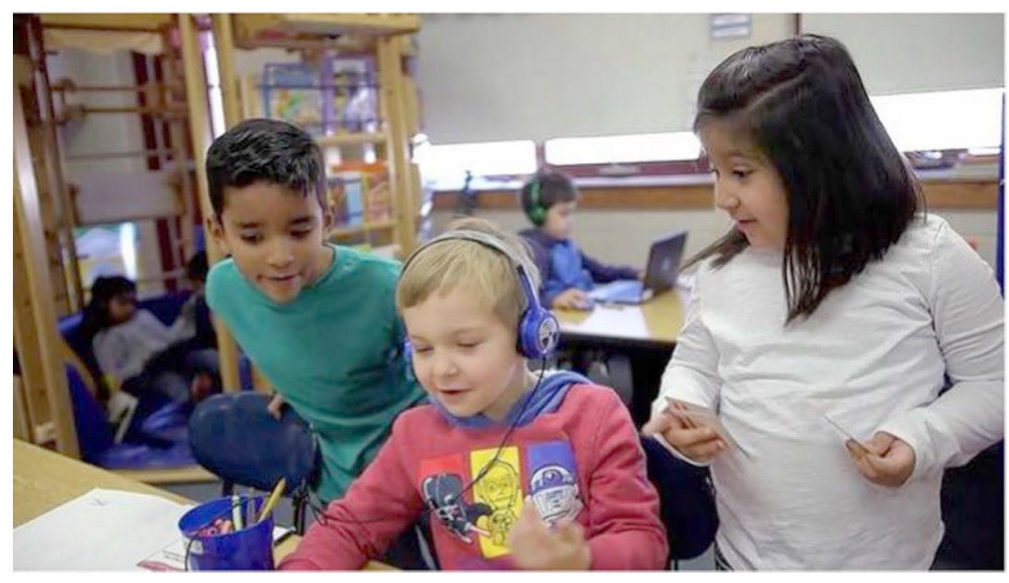

Figure 1 Students work on literacy activities in Jennifer Shamrylo's bilingual kindergarten classroom at Chesak Elementary School in Lake in the Hills. Huntley Community School District 158 this fall will launch a dual language program for kindergartners and first-graders at the school. Source Daily Herald. Reproduced with permission. Text 17: http://www.dailyherald.com/news/20180309/ district-158-to-launch-dual-language-program-this-fall\#comments

are constrained by the limitations in the information shared in and with such images. So, for example, we suggest in some images that a depicted student 'looks Latina.' We do not know if that indeed describes the background or affiliation of that subject, but we also know that other viewers similarly have no more information to interpret the image than we do. As such, 'what appears to be' can be visually more potent than any version of 'what really is'.

\section{Findings and discussion}

Our first image illustrates the subtle and nuanced ways in which the visual prioritizing of English-speaking families (e.g., world language constituencies) occurred in some of the data and one way in which gentrification trends can be seen in visual communication about the programs.

Figure 1 features three children as they work on "literacy activities" at an elementary school outside of Chicago, and the article announces a new two-way DL program in the district. Supported on each side by a Latino boy and Latina girl is a White boy. Their gaze 
is downward and they are all focused on the same thing (most likely a laptop given the child in the background has one). The White child in the center is wearing earphones while the other two children are not. Instead, the girl is carrying some cards, and both children are standing while the child in the middle is sitting down. The children's poses look as though they are passing by and have become interested in what the child in the center is doing. Here we are reminded of Susan Sontag's (1973) work in which she notes that photographs capture a thin slice of a moment in time. It is as if we are frozen in that quick moment, and all of the focus is on what the White boy is doing. This is interesting because it is not likely that the children stayed in this pose for very long. By freezing this moment, the photojournalist and editor give it priority.

The written information in the article is also important to consider in a multimodal analysis. The accompanying article here gives voice to the district curriculum and instruction director in the following direct quote: "Our English-speaking families have been waiting for this initiative for a long time," she said. "They are receiving dual language with open arms.” The quote exposes how world language (WL) constituencies are targeted in the article (since heritage/maintenance communities either do not speak English or are bilingual). This is accomplished in the subtle way that the photo elaborates (Barthes, 1977) by positioning the social actors in the photo as active or passive agents in material processes. The White child is not only shown in the center of the photo, he is the one that is more active by being engaged in the process of listening rather than just looking, as the other two Latinx students are doing.

This echoes Valdés's (1997: 417) “cautionary note” in which she observes how journalists that cover DL programs often concentrate on how well English-speaking children are learning Spanish while at the same time "ignoring how well a Spanish- speaking child is learning English.” Figure 1, which features the White child as the centerpiece and focal point of the image emerges as "a visual representation of the same phenomenon" (Catalano, 2020: 16). Consequently, this image (and others found in the data which subtly draw attention to White children in the programs), provides evidence of gentrification.

Figure 2 shows a similar trend in coverage of a Spanish DL program in Texas. The accompanying article informs us that the program began 


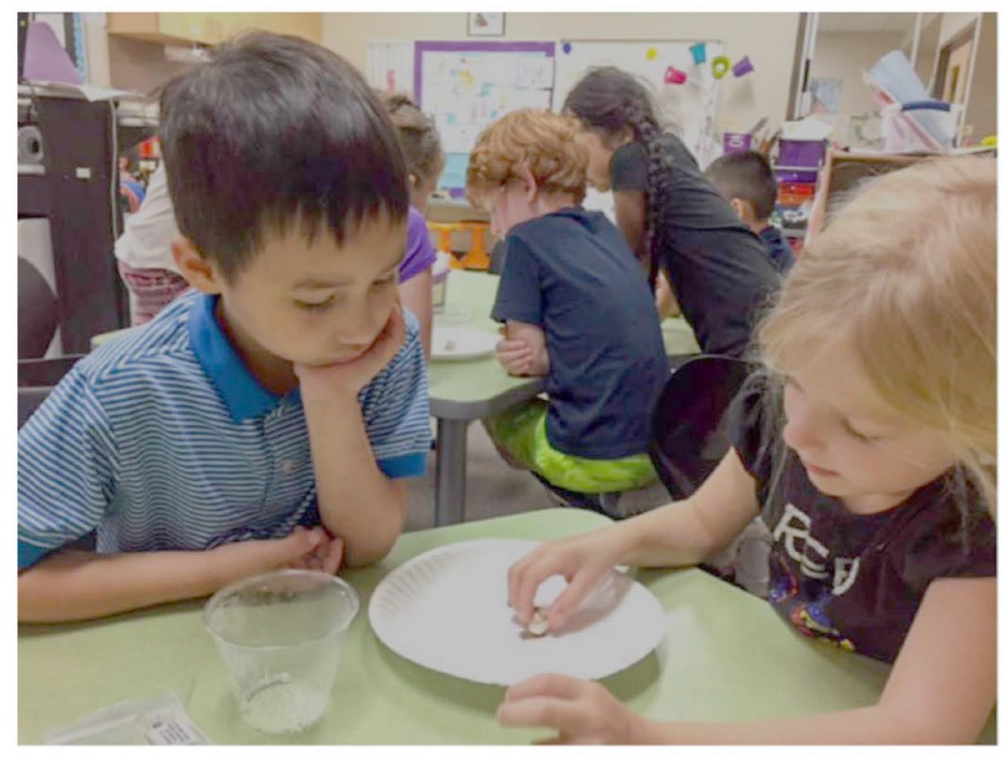

Two children in Leander ISD's two-way dual-language program share a table in their classroom. (Courtesy Leander ISD)

Figure 2 Source Community Impact Newspaper. Reproduced with permission. Text 24: https://communityimpact.com/austin/leander-cedar-park/editorspick/2018/05/24/leander-isd-expands-two-way-duallanguage-program-to-newschools-as-demand-rises/

in 2009 for "students who primarily speak Spanish to help them become proficient in English" (note the way in which Spanish is seen only as a gateway to English) but that the program now "differs in that primary Spanish and English speakers learn together, receiving lessons in both languages" (Bora, 2018, 3rd para.). The only parent quoted in the article is that of a parent of an English-speaking student. Figure 2 then visually reinforces this narrative of how children from different groups (although it is not clear if the boy on the left is a heritage/maintenance constituent or not) work together in the program, but focuses on the White girl as the active person in the activity, while the more Latino-appearing boy looks on.

So, although in both Figures 1 and 2 heritage/maintenance populations are included in the images, visual analysis reveals they are not protagonists in the photos, and the images are accompanied by written text that targets world language populations (a finding also found across the larger study (Catalano, 2020)). This may have been intentional because images can evoke emotional responses to the programs that could act as catalysts for a backlash (such as what happened in the 1980 s and $90 \mathrm{~s}$ when bilingual programs were accused of not 


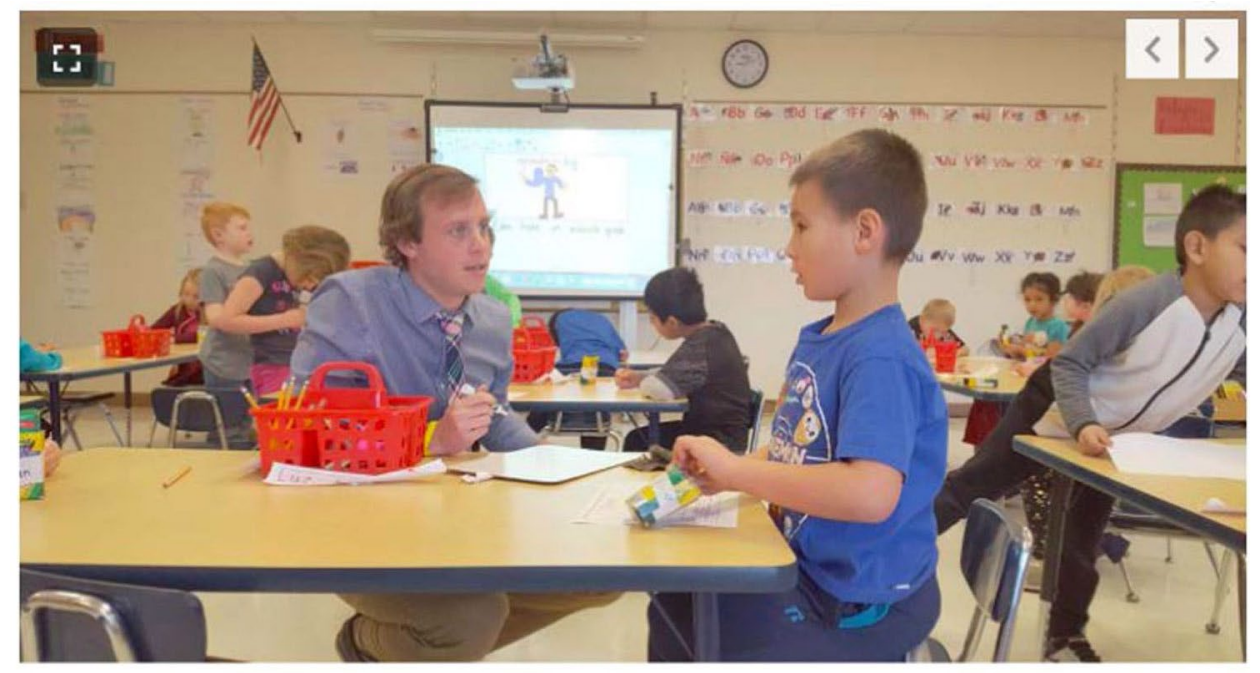

Dan Moran works with student Chase Nabity during his dual language class at Washington Elementary School on Tuesday.

JAMES FARRELL, Fremont Tribune

Figure 3 Source Fremont Tribune. Reproduced with permission. Reproduced with permission. Text 34: https://fremonttribune.com/news/local/education/washington-elementary-s-dual-language-programlooks-to-expand/article ebf28334-7d6o5eaf-ab7c-oe7219bca463.html

teaching English). As such, it is possible that the focus on White students in images was seen as a way to avoid such a reaction. Yet that explanation is not exoneration, it concedes to gentrification.

Figure 3 suggests concepts such as heritage and identity may be harder to communicate to anticipated viewers and include White (or world language constituent) points of entrée.

Although this program in a micropolitan town in Nebraska is twoway and features a close to equal balance between world language and heritage constituencies, the image makes it appear that most of the children (and the teacher) are White. Machin (2007: 129) notes that "changing position and groupings can change the whole meaning of the composition." In this case, we could imagine that a different camera angle might have captured more of the Latinx students in the classroom.

Interestingly, the most salient elements of the image are the teacher (lowered to the student's level with his whiteboard as if getting ready to write something for him) and the student (who looks to be retrieving something-probably a pencil- from a container and has a paper with writing on it). The image is an offer image, which invites us to 
observe, but not engage with the subjects. There is an equal camera angle and it is a relatively close-up shot, thus putting forth a relatively positive image of teacher and student. The student's race or ethnicity is ambiguous (but his name indexes Euro-American heritage), while the student directly behind him leaning to the right, as if reaching to grab something, appears to be Latino. The fact that this student's face is cut off indicates the reduced importance or salience given to him as a subject in the overall photograph.

When considering visual analysis, it is helpful to imagine all of the possibilities for representing an event in order to understand which viewpoint is being privileged. In this case, we can imagine what different values/ideologies would have been put forth had the photojournalist focused on the Latino boy in a close-up, and cut off the teacher's face or chose a different angle in which more of the Latinx students were included. We then need to question why (or how?) the photo depicts a class that appears to be more White than it was.

A close look at the history of Fremont, Nebraska, where the program exists, shows that the city has had negative press in the past with racism, in particular in regards to a housing ordinance (Sojico, 2014) that made landlords liable for renting to undocumented migrants and thus supported broader anti-Latino racial profiling. Knowing this context could explain why journalists might make special efforts to downplay (visually) who is actually benefiting from the program (as mentioned above), although the verbal text from the article does emphasize cultural benefits of the program in addition to academic and cognitive ones.

Hence, even though the program has been highly successful in a number of ways, ${ }^{2}$ it is clear that in the process of using the article to gain support for expansion of the program, it invoked the benefits to English-speaking families visually so as not to trigger community backlash in an area that largely consists of conservative voters and supporters of ant-immigration policies. But pre-emptively avoiding backlash reiterates hegemonic hierarchies, it is the prospectively reactionary White population that is being mollified.

2 We acknowledge that we know this program well, and have visited it several times, and one of us is quoted in the article. Hence, any conclusions about the program stem from what is presented in the article, but are also based on personal experience visiting the program. 


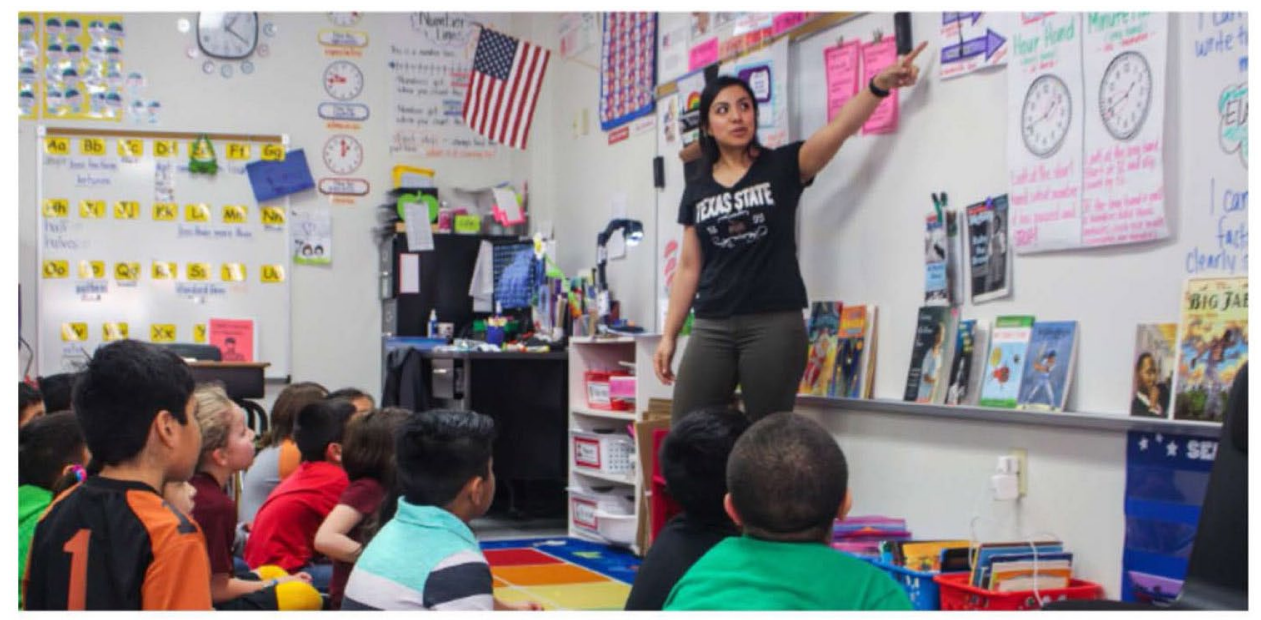

Daisy Saenz teaches a second-grade dual language class at Blanco Vista Elementary School.

Figure 4 Source Community Impact Newspaper. Reproduced with permission. Text 4: https://communityimpact.com/austin/san-marcos-buda-kyle/education/2018/03/19/hays-san-marcos-cisd-dual-language-programs-grow-officialslook-ways-around-bilingual-teacher-shortage/

Figure 4 offers an interesting comparison to Figure 3.

Figure 4 is a typical large group photo that emerged in the larger study depicting Spanish-English programs. The photo is from an article that discusses the growth of bilingual programs in the San Marcos areas of Texas and concerns about a bilingual teacher shortage in the area. As found in Coe and Kuttner (2018), this photo of a Spanish/ English program occurs in the context of a debate on bilingual education, whereas often Mandarin/English programs tend to be featured within the topic of global citizenship. Coe and Kuttner also note that numerically-less-common Mandarin programs receive more media coverage, and we found that they were overrepresented visually (as compared to the number of programs that exist) in our data as opposed to Spanish/English programs.

In contrast to Figure 3 in which there was a more close-up image and equal camera angle, most of the large group photos (including Figure 4) from the larger study followed a similar pattern: long distance camera shot of the teacher pointing at something or writing on the board, students' backs to the camera, no gaze or direct engagement by the subjects with the viewer, and downward camera angles (toward the students) which symbolize symbolic power over someone (van Leeuwen, 2008). There is little reason in this photo for a parent 
to want to enroll their child in this program. Moreover, because of the distance, the angle, the lack of gaze, and the fact that the children are pictured as part of a collective group of 'DL students', they are visually represented as 'Others'. The photos homogenize the students (most with similar hair and skin color, all sitting in similar poses) as a particular type, that is, part of the cultural group of Latinx and thus connote "the negative or positive values and associations attached" (van Leeuwen, 2008: 144) to this group, which in the current political zeitgeist, has been discriminatory and negative.

Figure 4 largely follows this pattern, with the exception of the face of a White girl in the center of the photo. Interestingly, although it is still an offer image, since we can only see the side of her face, we can still see her face more than all of the other children in the photo who appear to be Latinx. So, although the written text supports heritage/ maintenance populations in these programs, the accompanying visual (which readers/viewers would encounter first) tracks differently.

Figure 5 (from the same Nebraska article as Figure 3) is the only image that we share where the depicted language is the focus of the inquiry. It shows how languages are indicated by colors (to help students know how to pronounce words they see) but also to indicate which language should be spoken during particular times of the day (note the arrow pointing to Spanish in the photo).

We chose this photo because it highlights another aspect of the gentrification issue, which is how language policies are implemented. One way that program gentrification has been found to affect the language policies in schools is through language allocation. Research, such as Freire et al. (2017), has found that DL policies can adversely position the interests of Latinx students by restricting language time allocation models to 50-50 which center the needs of world-language constituencies. This is because often parents of English-speaking students become concerned that their children feel overwhelmed or lost in 90-10 models (in which 90\% of content is delivered in Spanish). 90-10 models have been shown to benefit all students but in particular (Thomas \& Collier, 2012) Spanish-speaking students in Spanish/ English programs.

Although in Nebraska, DL programs are not state-mandated, the implementation of language policies in classrooms there can also be affected by English-only families who are concerned about the academic 


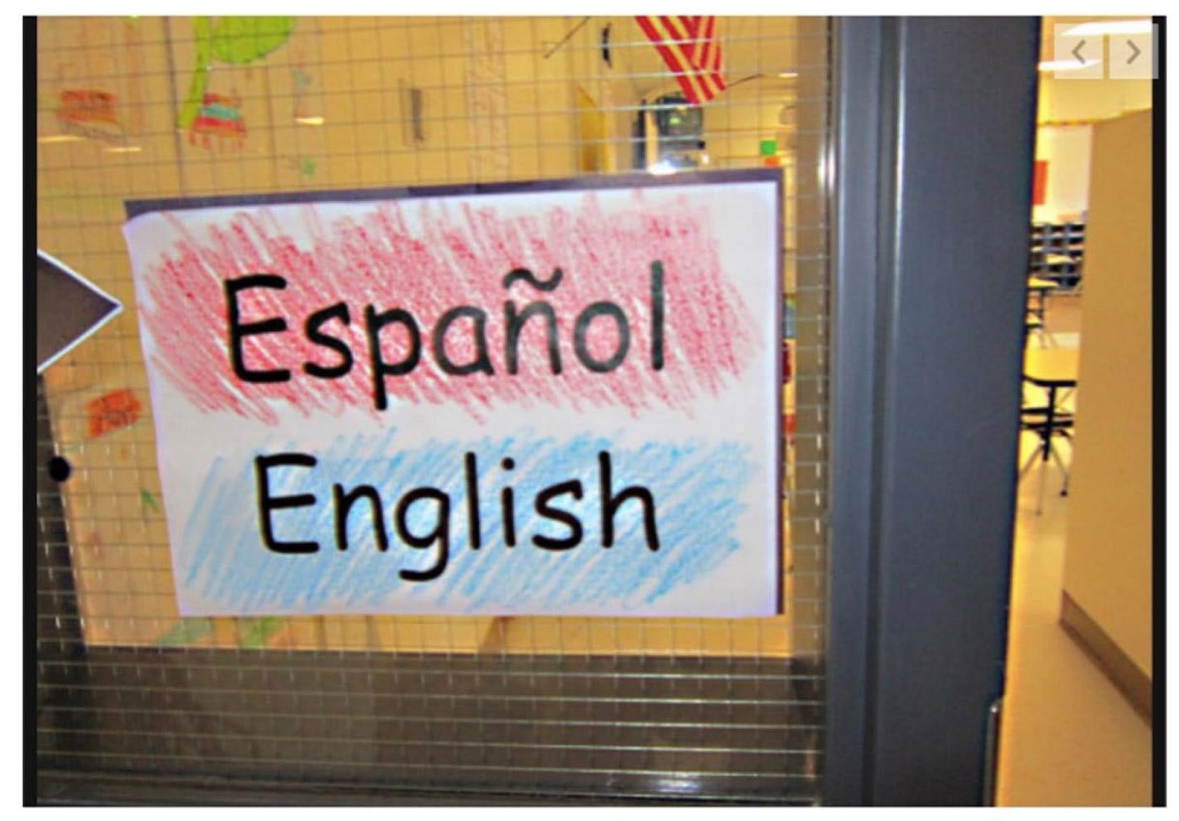

This photo shows a sign outside of the dual language class at Washington Elementary School in Fremont.

Figure 5 Source Fremont Tribune. Reproduced with permission. Text 34: https:// fremonttribune.com/news/local/education/washington-elementary-s-dual-language-program-looks-to-expand/article ebf28334-7d6o-5eaf-ab7c-oe7219bca463. html

achievement of their children. Although this photo does not indicate that this is happening in this program, it appears to naturalize a 50/50 distinction and a strict separation of languages, which DL advocates such as Thomas and Collier (2012) have traditionally argued for in order to ensure that languages other than English receive enough instructional time. However, in recent years, works by Ofelia García and others (e.g., García \& Kleyn, 2016; García et al. 2017; Menken \& García, 2021; Wei, 2018) have noted the problematic nature of language separation in that it does not recognize or value hybridity nor home language varieties that students speak, as well as the natural language practices of bilingual/multilingual learners referred to as translanguaging.

The Figure 5 sign helps students know which language the content will be delivered in, how to read the signs (red ones need Spanish pronunciation and blue ones use English pronunciation), but also communicates a separation of languages. While this could be counter-productive in that it communicates a strict separation between 
labeled languages, it can also be seen as a counter-resistance to pressure to reduce Spanish content time by first placing Spanish above in the sign (connoting its importance) and also by protecting the time allocation by signaling which language is dominant at that moment in time. This is more complicated than the other photos in the article which more clearly privilege world language constituencies.

\section{Conclusion}

The creators of the visual images accompanying print media (usually photojournalists) are not conventional creators of policy nor central to policy implementation, and we are not claiming otherwise, but they do help shape the public sphere that connects what the state does to what its populace wants (with some voices louder than others). These photojournalists and the editors who select which images to include with a story help shape the milieu in which DL programs operate.

MCDA allows researchers to consider representations of DL programs in the text and visual imagery of print media (both hard-copy newspapers and online versions), but that analysis can go further if also anchored to notions of the public sphere. Because of the two-way nature of the idea of the public sphere-(1) reflecting the considerations of civil society to the state, but (2) also having governmentality shape/normalize some ideas more than others back to society-, the public sphere helps convert the ideas of the populace into policy and practice of the state. The images we share show both the public getting from the state what it wants (i.e., DL programs of certain character) and the state offering certain things it hears the citizenry wanting. But this does not happen neutrally as an examination of the images reveals. Certain voices are privileged in the public sphere (e.g., White and mainstream), while others are limited. Similarly, gentrification privileges certain voices and minimizes (or excludes) others. As Johnson and Johnson (2015) note, what is supposed to happen as policy becomes practice is mediated by local actors (like teachers and parents) who feature/incorporate some sensibilities over others. This means the similarly designed can be differently implemented. We are proposing some of that difference in implementation comes from "habitual" (Spolsky, 2004) incorporation of public sphere imagery-i.e., parents, 
teachers, and photojournalists' varied consumption of and resonance with certain ideas of what their enactment of DL programs is to entail.

Our dataset of visual images does not show that gentrification is a dynamic visible in all representations of DL programs, but it does show how visual images can reinforce or normalize such understandings. LPP is concerned with inequalities of power, the ethics of program intentions and delivery, and the conversion of larger ideas and premises into daily practice. We propose that future LPP inquiry (not just about gentrification) can be advanced through increased study of visual depictions of DL programs with an understanding of how such imagery functions in the public sphere, ultimately reinforcing the apparent logic or desirability of certain ways of thinking and doing and leading us away from prospective others paradigms.

Yet this Special Issue demands more than acknowledgment that DL program gentrification is a relevant language policy issue. If, per an equity framing, the goals of many DL programs to serve heritage/ maintenance language populations is to be preserved or recovered, it is worth thinking about how the public sphere might be shaped to convey or protect such premises. That includes consideration of which civil society voices need to be more powerfully asserted to the state and, reflectively, what images might be shared back to celebrate, highlight, and/or naturalize heritage/ maintenance language populations' agentive inclusion. While it is hard to control what journalists and editors write, depict, or choose to convey, a closer look at Figure 2 reveals that it was a 'stock photo' provided by the school district. Clearly the images that a school district shares are in the control of that same district. As such district leaders can influence how various prospective constituencies are understood.

More broadly, the entities-parents, community leaders, and clearly some educators-who want to see heritage/maintenance populations prioritized and well-served by DL programs can be purposeful in how they advocate for and communicate about their programs. The task is not to argue against the presence of one population or another, but rather to argue for the expectation that heritage/maintenance students deserve places in DL programs as a prioritized constituency. In recent work describing the CUNY-New York State Initiative on Emergent Bilinguals, Menken and García (2021: 25) asserted that "for schools to be successful at meeting the needs of emergent bilingual 
students, they would need to develop broad ecologies of multilingualism that buil[d] on the home language practices of their students." It follows that from an MCDA perspective, the building of that ecology will not only be through the rhetoric that guides program implementation, but also through the visual imagery that more subtly shapes the public sphere's reflection of 'what should be.' The more possibilities for counter-hegemonic DL narratives available in the public sphere, even if subtly encoded within a visual, the more empowered educators will feel to stand up for marginalized students as they create, interpret, and appropriate policy.

\section{References}

Argyris, C., \& Schön, D. A. (1975). Theory in practice: Increasing professional effectiveness. Jossey- Bass Publishers.

Barthes, R. (1977). Image-music-text. Macmillan.

Bateman, J. A., \& Wildfeuer, J. (2014). A multimodal discourse theory of visual narrative. Journal of Pragmatics, 74, 180-208

Blommaert, J. (2013). Ethnography, superdiversity and linguistic landscapes: Chronicles of complexity (Vol. 18). Multilingual Matters.

Bora, A. (2018, May 24). Leander ISD expands two-way dual-language program to new schools as demand rises. Community Impact Newspaper. https:// communityimpact.com/austin/leandercedar-park/editors-pick/2018/05/24/ leander-isd-expands-two-way-dual-language-program-to-new-schools-asdemand-rises/

Burbules, N. C. (1996). Deconstructing "difference" and the difference this makes to education. Philosophy of Education, 114-123. Retrieved from http://ojs. ed.uiuc.edu/index.php/pes/index

Burns, M. (2017). "Compromises that we make": Whiteness in the dual language context. Bilingual Research Journal, 40(4), 339-352

Calhoun, C. (Ed.). (1992). Habermas and the Public Sphere. MIT Press.

Catalano, T. (2020). The visual representation of dual language education. Visual Communication. https://doi.org/10.1177/1470357220904395

Coe, K., \& Kuttner, P. J. (2018). Education coverage in television news: A typology and analysis of 35 years of topics. AERA Open, 4(1), 2332858417751694

Combs, M. C., González, N., \& Moll, L. (2011). US Latinos and the learning of English: The metonymy of language policy. In T. L. McCarty (Ed.), Ethnography and language policy. (pp. 128-135). Routledge.

Delavan, M. G., Valdez, V. E., \& Freire, J. A. (2017). Language as whose resource?: When global economics usurp the local equity potentials of dual language education. International Multilingual Research Journal, 11(2), 86-100 
Flores, N. (2016). A tale of two visions: Hegemonic whiteness and bilingual education. Educational Policy, 30(1), 13-38

Fraser, N. (1992). Rethinking the public sphere: A contribution to the critique of actually existing democracy. In C. Calhoun (Ed.), Habermas and the public sphere. (pp. 109-142). MIT Press.

Freire, J. A., Valdez, V. E., \& Delavan, M. G. (2017). The (dis) inclusion of Latina/o interests from Utah's dual language education boom. Journal of Latinos and Education, 16(4), 276-289

García, O., Johnson, S. I., \& Seltzer, K. (2017). The translanguaging classroom: Leveraging student bilingualism for learning. Caslon.

García, O., \& Kleyn, T. (Eds.). (2016). Translanguaging with multilingual students: Learning from classroom moments. Routledge.

Garnham, N. (1992). The media and the public sphere. In C. Calhoun (Ed.), Habermas and the public sphere. (pp. 359-376). MIT Press.

Gerstl-Pepin, C. I. (2007). Introduction to the special issue on the media, democracy, and the politics of education. Peabody Journal of Education, 82(1), 1-9

Goffman, E., \& Rodríguez, J. L. (2006). Frame analysis: los marcos de la experiencia. Centro de Investigaciones Sociológicas.

Habermas, J. (1962 trans 1989) The Structural Transformation of the Public Sphere: An Inquiry into a category of Bourgeois Society, Cambridge, UK: Polity.

Hamann, E. T., \& Reeves, J. (2012). ICE raids, children, media and making sense of Latino newcomers in flyover country. Anthropology \& Education Quarterly, 43(1), 24-40

Heiman, D., \& Murakami, E. (2019). "It was like a magnet to bring people in": School administrators' responses to the gentrification of a two-way bilingual education (TWBE) program in central Texas. Journal of School Leadership. https://doi.org/10.1177/1052684619864702

Heiman, D., \& Yanes, M. (2018). Centering the fourth pillar in times of TWBE gentrification: "Spanish, love, content, not in that order." International Multilingual Research Journal, 12(3), 173-187

Henderson, K. I. (2019). The danger of the dual-language enrichment narrative: Educator discourses constructing exclusionary participation structures in bilingual education. Critical Inquiry in Language Studies, 16(3), 155-177

Henderson, K. I., \& Palmer, D. K. (2020). Dual Language Bilingual Education: Teacher Cases and Perspectives on Large-scale Implementation. Multilingual Matters.

Howard, E. R., Sugarman, J., Christian, D., Lindholm-Leary, K. J., \& Rogers, D. (2007). Guiding principles for dual language education. Center for Applied Linguistics.

Howell, W. (2008). Education policy, academic research, and public opinion. In F. Hess (Ed.), When research matters: How scholarship influences education policy. (pp. 135-153). Harvard Education Press. 
Hult, F. M. (2018). Language policy and planning and linguistic landscapes. In J. W. Tollefson \& M. Pérez-Milans (Eds.), The Oxford handbook of language policy and planning. (pp. 333-351). Oxford University Press.

Jewitt, C., Bezemer, J., \& O’Halloran, K. (2016). Introducing multimodality. Routledge.

Johnson, D. C., \& Johnson, E. J. (2015). Power and agency in language policy appropriation. Language Policy, 14(3), 221-243

Kress, G., \& van Leeuwen, T. (2006). Reading images: The grammar of visual design (2nd ed.). Routledge.

Ledin, P., \& Machin, D. (2018). Doing visual analysis: From theory to practice. Sage.

Lipsky, Michael (1969). Toward a Theory of Street-Level Bureaucracy (IRP Discussion Papers No. 48-69) (p. 45). Madison, WI: Institute for Research on Poverty (IRP), University of Wisconsin

Lutz, C. A., \& Collins, J. L. (1993). Reading national geographic. (Vol. 59)University of Chicago Press.

Machin, D. (2007). Introduction to multimodal analysis. Hodder Arnold.

Machin, D., \& Van Leeuwen, T. (2016). Multimodality, politics and ideology. Journal of Language and Politics, 15(3), 243-258

Menken, K., \& García, O. (2021). Constructing translanguaging school policies and practices. In: CUNY-New York State Initiative on Emergent Bilinguals (Eds.) Translanguaging and transformative teaching for emergent bilingual students. Routledge.

Palmer, D. (2010). Race, power, and equity in a multiethnic urban elementary school with a dual-language "strand" program. Anthropology and Education Quarterly, 41(1), 94-114

Palmer, D., \& Martínez, R. A. (2013). Teacher agency in bilingual spaces: A fresh look at preparing teachers to educate Latina/o bilingual children. Review of Research in Education, 37(1), 269- 297. https://doi. org/10.3102/o091732X12463556

Sojico, J. (2014, June 6). Fremont's housing ordinance is in effect, but difficult to enforce. NET. http://netnebraska.org/article/news/921130/ fremonts-housing-ordinance-effect-difficult-enforce

Sontag, S. (1973). On photography. Allen Lane.

Spolsky, B. (2004). Language policy. Cambridge University Press.

Thomas, W. P., \& Collier, V. P. (2012). Dual language education for a transformed world. Dual Language Education of New Mexico/Fuente Press.

Valdés, G. (1997). Dual language immersion programs: A cautionary note concerning the education of language-minority students. Harvard Educational Review, 67(3), 391-429

Valdez, V. E., Freire, J. A., \& Delavan, M. G. (2016). The gentrification of dual language education. The Urban Review, 48(4), 601-627 
van Dijk, T. (1988). News Analysis. Case studies of international and national news in the press. Erlbaum.

van Leeuwen, T. (2008). Discourse and practice: New tools for critical discourse analysis. Oxford University Press.

Wei, L. (2018). Translanguaging as a practical theory of language. Applied Linguistics, 39(1), 9-30

West, D. M., Whitehurst, G. J., \& Dionne, E. J. (2011). Americans want more coverage of teacher performance and student achievement. Brookings Institution.

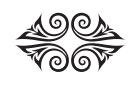

Edmund T. Hamann is a Professor in the Dept. of Teaching, Learning, \& Teacher Education at the University of Nebraska-Lincoln and the current President of the American Anthropology Association's Council on Anthropology and Education. Inducted as an AERA Fellow in 2020 by the American Education Research Association, he is particularly interested in local development of educational policy in response to demographic change, particularly in response to the transnational movement of children and their families. This includes considering whether/how linguistic diversity is viewed as an asset by educators and which school constituencies they prioritize. He is (co)author of more than 75 journal articles and book chapters and (co)author/(co)editor of 13 books, monographs, and special journal issues, including the forthcoming Lo que los maestros mexicanos requieren conocer de la educación básica en Estados Unidos (What Mexican Teachers Need to Know about Elementary and Secondary Education in the United States).

Theresa Catalano is an Associate Professor in the Dept. of Teaching, Learning, \& Teacher Education at the University of Nebraska-Lincoln (UNL). Her teaching and scholarship focus on language teacher education and migration (including intercultural education and arts integration) and the connection of language and visual communication to ideology, power, and social inequality. She is the founding coordinator of UNL's dual language teaching endorsement pathway and current coordinator of the ' $M$-cubed' initiative on Migration, Multilingualism, and Multiculturalism. She is author of 45 journal articles and book chapters, plus three books, including the recent Critical Discourse Analysis, Critical Discourse Studies and Beyond (2020, Springer Nature) with Linda Waugh. 